\title{
Ocena stopnia zaawansowania i odpowiedzi na leczenie u chorych na chłoniaka Hodgkina i chłoniaki nie-Hodgkina - rekomendacje Międzynarodowej Grupy Roboczej z Lugano
}

\author{
Evaluation of initial staging and treatment response \\ for Hodgkin and non-Hodgkin lymphoma patients \\ - recommendations of the International \\ Working Group from Lugano
}

\author{
Ewa Lech-Marańda ${ }^{1,2}$, Krzysztof Warzocha ${ }^{1}$ \\ ${ }^{1}$ Klinika Hematologii, Instytut Hematologii i Transfuzjologii, Warszawa \\ ${ }^{2}$ Klinika Hematologii i Transfuzjologii, Centrum Medyczne Kształcenia Podyplomowego, Warszawa
}

\begin{abstract}
Streszczenie
W pracy przedstawiono aktualne rekomendacje dotyczqce oceny stopnia zaawansowania $i$ odpowiedzi na leczenie u chorych na chtoniaka Hodgkina (HL) i chtoniaki nie-Hodgkina opracowane podczas 12. Międzynarodowej Konferencji Chtoniaków Ztośliwych w Lugano. Badanie pozytonowej tomografi emisyjnej z zastosowaniem fluorodeoksyglukozy (FDG) w potaczeniu z tomografia komputerowa (PET-CT) powinno być standardem w przypadku chtoniaków FDG-awidnych, zarówno przy rozpoznaniu, jaki $i$ przy ocenie odpowiedzi. W przypadku chtoniaków FDG-nieawidnych należy wykonywać badanie CT. Przy rozpoznaniu badanie trepanobiopsyjne szpiku może nie być konieczne, szczególnie $w$ HL $i$ większości przypadków chtoniaków rozlanych $z$ duzych komórek $B$. W rutynowej obserwacji po leczeniu nie zaleca sie badań PET-CT ani CT.
\end{abstract}

Słowa kluczowe: chłoniak Hodgkina, chłoniaki nie-Hodgkina, pozytonowa tomografia emisyjna, FDG-awidny, FDG-nieawidny, rekomendacje

Hematologia 2015; 6, 3: 223-232

\begin{abstract}
Current recommendations are discussed for initial evaluation, staging, and response assessment of patients with Hodgkin lymphoma (HL) and non-Hodgkin lymphoma; these having been established at the $12^{\text {th }}$ International Conference on Malignant Lymphoma in Lugano. As a result, fuorodeoxyglucose (FDG) positron emission tomography-computed tomography (PET-CT) was formally incorporated into standard staging for FDG-avid lymphomas whereas CT is preferred for staging of FDG-nonavid lymphomas. A bone marrow biopsy is now no longer indicated for routine staging of HL and most diffuse large B-cell lymphomas. Routine surveillance scans are also discouraged.
\end{abstract}

Key words: Hodgkin lymphoma, non-Hodgkin lymphoma, positron emission tomography, FDG-avid, FDG-nonavid, recommendations

Hematologia 2015; 6, 3: 223-232

Adres do korespondencji: Ewa Lech-Marańda, Klinika Hematologii, Instytut Hematologii i Transfuzjologii, ul. Indiry Gandhi 14, 02-776 Warszawa, tel. 223496 334, faks 223496 335, e-mail: emaranda@ihit.waw.pl 


\section{Wprowadzenie}

W ostatnich latach dokonal się istotny postęp w poznaniu patogenezy nowotworów układu chłonnego. $Z$ jednej strony poznanie molekularnych mechanizmów odpowiedzialnych za podtrzymanie proliferacyjnego potencjału tych nowotworów umożliwiło wprowadzenie nowych metod terapii. $Z$ drugiej strony dynamiczny rozwój technik radiologicznych umożliwia wczesne wykrycie nowotworów oraz bardziej precyzyjną ocenę stopnia ich zaawansowania i odpowiedzi na leczenie. Osiagnnięcia te spowodowały konieczność zaktualizowania obowiązujących dotychczas klasyfikacji - zarówno służących do oceny stopnia klinicznego zaawansowania nowotworu w momencie rozpoznania, jak i obejmujących kryteria oceny odpowiedzi na leczenie.

Dotychczas obowiązującą klasyfikacją służącą ocenie stopnia zaawansowania klinicznego chorych na chłoniaka Hodgkina (HL, Hodgkin lymphoma) i chłoniaki nie-Hodgkina (NHL, non-Hodgkin lymphoma) była klasyfikacja $z$ Ann Arbor [1]. W 1989 roku opublikowano jej modyfikację $z$ Cotswold wprowadzającą do oceny zaawansowania nowotworu technikę tomografii komputerowej (CT, computed tomography) oraz określenie „X” na obecność zmiany masywnej (bulky tumor) [2]. W celu oceny skuteczności leczenia początkowo stosowano kryteria zaproponowane przez International Workshop to Standardize Response Criteria for Non-Hodgkin Lymphomas z 1999 roku [3]. Ich podstawami były badanie podmiotowe i przedmiotowe oraz określenie wymiarów węzłów chłonnych metodą CT i ocena zajęcia szpiku kostnego (BM, bone marrow) w trepanobiopsji. W powyższych kryteriach wprowadzono również pojęcie tak zwanej całkowitej remisji niepotwierdzonej (CRu, complete remission unconfirmed) na określenie masy rezydualnej składającej się najprawdopodobniej z tkanki włóknistej, która pozostaje u pacjenta po zakończeniu leczenia. $\mathrm{W}$ przypadku chłoniaków rozlanych $Z$ dużych komórek B (DLBCL, diffuse large B-cell lymphoma) i HL, ale nie w pozostałych chłoniakach, kryteria te zaktualizowano w International Harmonization Project w 2007 roku, poprzez włączenie zarówno $\mathrm{w}$ proces diagnostyczny, jak i oceny po leczeniu badań immunohistochemicznych i cytometrii przeplywowej szpiku kostnego oraz badania pozytonowej tomografii emisyjnej (PET, positron emission tomography) całego ciała [4]. W ten sposób uprzednia kategoria CRu przestała istnieć, gdyż wątpliwe przypadki rozstrzygano w badaniu PET.

W 2013 roku, podczas 12. Międzynarodowej Konferencji Chłoniaków Złośliwych (ICML, In- ternational Conference on Malignant Lymphoma) w Lugano, sformułowano modyfikację wymienionych wyżej klasyfikacji, którą opublikowano w 2014 roku w ,Journal of Clinical Oncology” [5]. W niniejszej pracy omówiono rekomendacje Międzynarodowej Grupy Roboczej z Lugano odnoszące się do oceny stopnia zaawansowania i odpowiedzi na leczenie u chorych na HL i NHL.

\section{Rozpoznanie i ocena stopnia zaawansowania}

\section{Rozpoznanie}

Rozpoznania HL i NHL należy dokonywać wyłącznie na podstawie badania histopatologicznego, do którego należy pobrać cały węzeł chłonny lub fragment zajętego narządu. Ocenę morfologiczną należy rozszerzyć o badania immunofenotypowe $z$ wykorzystaniem przeciwciał monoklonalych, nakładanych na skrawki materiału histopatologicznego metodą immunohistochemiczną i/lub do zawiesiny komórek uzyskanych $z$ materiału bioptycznego metodą cytometrii przepływowej, a także o badania molekularne, jeśli są konieczne do określenia podtypu chłoniaka. Wykonanie jedynie aspiracyjnej biopsji cienkoigłowej (fine-needle aspirate biopsy) nie wystarcza, by postawić diagnoze HL i NHL. Biopsję gruboigłową (core-needle biopsy) można wykorzystać, jeśli w momencie rozpoznania nie jest możliwe pobranie ani fragmentu (incisional biopsy), ani całego (excisional biopsy) węzła/tkanki. Biopsję gruboigłową można również stosować do udokumentowania nawrotu choroby [5].

\section{Badanie podmiotowe i przedmiotowe}

U każdego chorego $z$ rozpoznaniem chłoniaka należy przeprowadzić dokładne badanie podmiotowe i przedmiotowe. $\mathrm{W}$ badaniu podmiotowym trzeba zwrócić szczególną uwagę na wiek, choroby wspólistniejące (comorbidities) i wcześniejsze choroby nowotworowe. Ponadto u starszych chorych istotnym elementem badania jest oszacowanie ryzyka wystąpienia poważnych powikłań indukowanych chemioterapia poprzez przeprowadzenie tak zwanej całościowej oceny geriatrycznej (CGA, Comprehensive Geriatric Assessment). W tym celu wykorzystuje się między innymi skalę oceny podstawowych (ADL, Activities of Daily Living) lub złożonych (iADL, instrumental ADL) czynności dnia codziennego oraz skale służące do oceny wpływu chorób wspólistniejących na przewidywane przeżycie chorego, takie jak indeks chorób towarzyszących/współistniejących według Charlson (CCI, Charlson Comorbidity Index) oraz CIRS-G 
(Cumulative Illness Rating Scale for Geriatrics). Skale te omówiono we wcześniejszych artykułach opublikowanych w czasopiśmie „Hematologia” [6].

Zgodnie z klasyfikacją z Lugano objawy ogólne choroby (objawy B), takie jak gorączka powyżej $38^{\circ} \mathrm{C}$ trwająca bez uchwytnej przyczyny dłużej niż 2 tygodnie i/lub poty nocne, i/lub chudnięcie, tj. utratę co najmniej $10 \%$ masy ciała w czasie nie dłuższym niż 6 miesięcy, należy oceniać jedynie u chorych na HL, bo tylko w tej populacji chorych wykazano ich znaczenie prognostyczne [5]. Trzeba pamiętać, że ponowne pojawienie się wyżej wymienionych objawów w trakcie leczenia lub po jego zakończeniu może zwiastować nawrót/progresję choroby. U pacjentów $z$ innymi rodzajami chłoniaków, między innymi z DLBCL, chłoniakiem grudkowym (FL, follicular lymphoma) czy chłoniakiem z komórek płaszcza (MCL, mantle cell lymphoma), nie rekomenduje się już oceny objawów B, gdyż nie wiążą się one $z$ niekorzystnym rokowaniem [5].

Badanie przedmiotowe powinno obejmować między innymi ocenę stanu ogólnego chorego na podstawie kryteriów zaproponowanych przez Eastern Cooperative Study Group (ECOG) oraz ocenę wymiarów dostępnych węzłów chłonnych, a także śledziony i wątroby mierzonych odpowiednio poniżej lewego i prawego luku żebrowego $\mathrm{w}$ linii środkowo-obojczykowej.

\section{Badania laboratoryjne}

Spośród badań laboratoryjnych, niezależnie od typu chłoniaka, w każdym przypadku należy skontrolować morfologię krwi obwodowej, biochemiczne parametry wydolności wątroby i nerek, w tym klirens kreatyniny, aktywność dehydrogenazy mleczanowej (LDH, lactate dehydrogenase), proteinogram i immunoelektroforezę, a także dokonać wirusologicznej oceny zakażeń ludzkim wirusem niedoboru odporności (HIV, human immunodeficiency virus), wirusem zapalenia wątroby typu B (HBV, hepatitis $B$ virus) i typu C (HCV, hepatitis $C$ virus), wirusem Epstein-Barr (EBV, Epstein-Barr virus) oraz przeprowadzić badanie ultrasonograficzne (USG) serca wraz z oceną frakcji wyrzutowej lewej komory w uzasadnionych klinicznie przypadkach, $\mathrm{w}$ tym u chorych w podeszłym wieku. U chorych $z$ dodatnim wywiadem $\mathrm{w}$ kierunku przewlekłych chorób układu oddechowego i/lub z objawami klinicznymi wskazane może być wykonanie badania spirometrycznego.

Bardzo ważnym elementem początkowej oceny chorego jest określenie czynników rokowniczych i wskaźników prognostycznych charakterystycznych dla danego typu chłoniaka, w tym
IPI (International Prognostic Index) w przypadku DLBCL i innych chłoniaków agresywnych, FLIPI (Follicular Lymphoma International Prognostic Index) $\mathrm{w}$ odniesieniu do FL czy MIPI (MCL International Prognostic Index) chorych na MCL [7-9].

\section{Badania obrazowe}

Ze względu na fakt istotnych interpersonalnych różnic w ocenie przedmiotowej węzłów chłonnych oraz śledziony i wątroby, według obecnie obowiązującej klasyfikacji z Lugano, ocenę zajętych narządów i tkanek należy prowadzić na podstawie badania PET-CT $\mathrm{w}$ chłoniakach fluorodeoksyglukozo (FDG, fluorodeoxyglucose)-awidnych i CT w chłoniakach FDG-nieawidnych (tab. 1). Większość chłoniaków jest awidna w badaniu PET, a ogniskowy wychwyt FDG w zmianie węzłowej lub pozawęzłowej - zgodnie z 5-punktową skalą (5PS, 5-point scale) i /lub charakterystycznym obrazem w badaniu CT - jest uważany za zajęcie takiego węzła/narządu pozawęzłowego przez chłoniaka.

Do chłoniaków FDG-nieawidnych należą przewlekła białaczka limfocytowa (CLL, chronic lymphocytic leukemia)/chłoniak z małych limfocytów (small lymphocytic lymphoma), chłoniak limfoplazmocytowy (LPL, lymphoplasmacytic lymphoma)/makroglobulinemia Waldenströma (WM, Waldenström's macroglobulinemia), chłoniaki strefy brzeżnej (MZL, marginal zone lymphoma) oraz ziarniniak grzybiasty (MF, mycosis fungoides). W przypadku chłoniaków FDG-nieawidnych ocenę wstępną, etapową i po zakończeniu leczenia należy prowadzić na podstawie badania CT (tab. 1).

Zaleca się wybranie do 6 największych, dominujących węzłów chłonnych, mas węzłowych lub innych zmian limfatycznych mierzalnych w dwóch wymiarach, tj. najdłuższym poprzecznym (LDi, longest transverse diameter of a lesion) oraz najkrótszym podłużnym prostopadłym do LDi (SDi, shortest axis perpendicular to the LDi). Powyzisze zmiany powinny być reprezentatywne i zlokalizowane $\mathrm{w}$ różnych regionach ciała, i - jeśli ma to zastosowanie - powinny obejmować śródpiersie i okolicę pozaotrzewnową. Mierzalne węzły chłonny muszą mieć LDi powyżej $1,5 \mathrm{~cm}$. Mierzalne zmiany pozawęzłowe, takie jak na przykład guzki w wątrobie, mogą obejmować 6 reprezentatywnych zmian, a LDi zmiany musi być większe niż $1 \mathrm{~cm}$. Do zmian niemierzalnych zalicza się wszystkie zmiany niezakwalifikowane jako mierzalne; mogą dotyczyć węzłów chłonnych, mas węzłowych lub zmian pozawęzłowych, których nie uznano za dominujące lub mierzalne albo zmian, których nie można zmierzyć w dwóch wymiarach lub monito- 
Tabela 1. Kryteria oceny zajęcia narządów/tkanek przez chłoniaka według klasyfikacji z Lugano (źródło [5])

Table 1. Criteria for involvement site according to the Lugano classification (source [5])

\begin{tabular}{|c|c|c|c|c|}
\hline Narząd/tkanka & Ocena kliniczna & Wychwyt FDG & Badanie obrazowe & $\begin{array}{l}\text { Zajęcie wskazujące } \\
\text { na chłoniaka }\end{array}$ \\
\hline \multirow[t]{2}{*}{ Węzły chłonne } & Wyczuwalne & Chłoniak awidny & PET-CT & Zwiększony wychwyt FDG \\
\hline & Wyczuwalne & Chłoniak nieawidny & $\mathrm{CT}$ & $\begin{array}{l}\text { Powiększenie węzłów } \\
\text { chłonnych niewyjaśnione } \\
\text { inną przyczyną }\end{array}$ \\
\hline \multirow[t]{2}{*}{ Śledziona } & $\begin{array}{l}\text { Wyczuwalna, } \\
\text { powiększona }\end{array}$ & Chłoniak awidny & PET-CT & $\begin{array}{l}\text { Rozlany wychwyt FDG, } \\
\text { pojedyncza zmiana, } \\
\text { zmiany prosówkowate, } \\
\text { guzki }\end{array}$ \\
\hline & & Chłoniak nieawidny & $\mathrm{CT}$ & $\begin{array}{l}>13 \mathrm{~cm} \text { długości piono- } \\
\text { wej, naciek, guzki }\end{array}$ \\
\hline \multirow[t]{2}{*}{ Wątroba } & $\begin{array}{l}\text { Wyczuwalna, } \\
\text { powiększona }\end{array}$ & Chłoniak awidny & PET-CT & Rozlany wychwyt FDG \\
\hline & & Chłoniak nieawidny & $\mathrm{CT}$ & Guzki \\
\hline \multirow[t]{3}{*}{ OUN } & $\begin{array}{l}\text { Objawy podmiotowe } \\
\text { i przedmiotowe }\end{array}$ & & $\mathrm{CT}$ & $\begin{array}{l}\text { Zmiana/y naciekowe } \\
\text { w mózgowiu }\end{array}$ \\
\hline & & & MRI & $\begin{array}{l}\text { Naciek opon mózgowo- } \\
\text {-rdzeniowych, zmiany } \\
\text { naciekowe w mózgowiu }\end{array}$ \\
\hline & & & CSF & $\begin{array}{l}\text { Cytologia, badanie } \\
\text { immunofenotypowe }\end{array}$ \\
\hline $\begin{array}{l}\text { Inne: skóra, płuca, } \\
\text { przewód pokarmowy, } \\
\text { kości, szpik kostny }\end{array}$ & $\begin{array}{l}\text { Objawy zależne } \\
\text { od lokalizacji }\end{array}$ & & PET-CT* biopsja & Naciek chłoniakowy \\
\hline
\end{tabular}

rować ilościowo, w tym: wysięki opłucnowe, okołoosierdziowe lub wewnątrzotrzewnowe, zajęcie skóry, kości, przewodu pokarmowego, śledziony, wątroby, nerek, opon mózgowo-rdzeniowych, masy w jamie brzusznej i inne zmiany, które nie mogą być potwierdzone ani monitorowane za pomocą badań obrazowych [5].

W przypadku trudności z postawieniem rozpoznania histopatologicznego chłoniaka lub podejrzenia transformacji chłoniaka FDG-nieawidnego w chłoniaka agresywnego badanie PET-CT może pomóc w identyfikacji najbardziej odpowiedniego narządu/tkanki do wykonania weryfikującej biopsji [5].

U chorych na HL zmianę masywną (bulky) definiuje się $\mathrm{w}$ badaniu CT jako pojedynczą masę węzłową (a nie liczne, małe węzły chłonne), której wymiar jest większy bądź równy $10 \mathrm{~cm}$ lub większy niż 1/3 poprzecznego wymiaru klatki piersiowej mierzonego na poziomie dowolnego kręgu piersiowego. U chorych na NHL wymiar zmiany bulky nie został jednoznacznie zdefiniowany w odniesieniu do korelacji $z$ odległymi wynikami leczenia. Przy obecnych standardach leczenia indukującego, obejmujących stosowanie rytuksymabu, według
Federico i wsp. [10] u chorych na FL za zmianę bulky uważa się taką największą zmianę węzłową, której najdłuższy wymiar przekracza $6 \mathrm{~cm} . Z$ kolei u chorych na DLBCL, według klasyfikacji z Lugano, minimalny wymiar zmiany węzłowej, którą można uznać za zmianę bulky, określa się zmianę powyżej $6 \mathrm{~cm}$ lub ponad 10-centymetrową [5]. Na podstawie badania MInT (MabThera International Trial) [11] dla zmiany bulky zlokalizowanej w śródpiersiu przyjęto wymiar co najmniej $10 \mathrm{~cm}$ i do 2014 roku podobny wymiar zmiany bulky rekomendowano w zaleceniach National Comprehensive Cancer Network (NCCN) [12]. Należy jednak zauważyć, że według zaleceń NCCN z 2015 roku (wersja 2.), uwzględniających nową klasyfikację $z$ Lugano, za minimalny wymiar zmiany bulky uznaje się $7,5 \mathrm{~cm}$ [13]. Obecnie nie zaleca się już rutynowego wykonywania badania rentgenowskiego (RTG) klatki piersiowej ani przy ocenie stopnia zaawansowania chłoniaka, ani przy ocenie masy bulky w śródpiersiu [5].

Według rekomendacji z Lugano za powiększenie śledziony uznaje się jej pionowy wymiar powyżej $13 \mathrm{~cm}$. Należy podkreślić, że śledziona może być nacieczona przez chłoniaka nawet przy prawid- 
łowych wymiarach, ale również jej powiększenie może być wynikiem zwiększonej objętości krwi, stosowania krwiotwórczych czynników wzrostu lub może być spowodowane innymi przyczynami niezwiązanymi $z$ nowotworem układu chłonnego. Zajęcie śledziony przez chłoniak można najlepiej ocenić w badaniu PET-CT jako jej homogenne powiększenie, rozlany naciek ze zmianami ogniskowymi, ogniskowe zmiany guzkowe lub jeden duży naciek. Badanie PET-CT jest również najlepszą metodą do oceny zajęcia wątroby przez proces chłoniakowy, w którym stwierdza się zwiększony, rozlany lub ogniskowy wychwyt FDG z ogniskowymi czy rozsianymi guzkami lub bez nich [5].

\section{Trepanobiopsja szpiku kostnego}

W nowej klasyfikacji z Lugano zmianie uległy rekomendacje dotyczące konieczności wykonywania trepanobiopsji BM przy rozpoznaniu HL i DLBCL. Uważa się, że w tych typach chłoniaków wysoka czułość badania PET-CT może zastąpić badanie trepanobiopsyjne BM. Wykazano bowiem, że u chorych na HL we wczesnych stadiach choroby rzadko obserwuje się nacieki w BM, jeśli takiego zajęcia nie uwidoczniono $\mathrm{w}$ badaniu PET-CT. $Z$ kolei u chorych $w$ stadiach zaawansowanych rzadko stwierdza się zajęcie szpiku przez HL, jeśli nie występują objawy zależne od choroby czy inne cechy wskazujące na zaawansowane stadium chłoniaka. W badaniu El-Galaly i wsp. [14], obejmującym chorych w zaawansowanym stadium HL, u $18 \%$ obserwowano ogniskowe zmiany w układzie kostnym w badaniu PET-CT, a tylko u $6 \%$ z nich stwierdzono nacieczenie BM w badaniu trepanobiopsyjnym. Dlatego, jeśli wykonuje się badanie PET-CT przy rozpoznaniu HL, to nie rekomenduje się już trepanobiopsji BM.

U chorych na DLBCL badanie PET-CT jest również bardziej czułe niż trepanobiopsja w ocenie zajęcia BM przez proces chłoniakowy, chociaż obserwowano, że badanie PET-CT może nie wykazać obecności DLBCL przy 10-20-procentowym nacieczeniu szpiku [15-18]. Niemniej jednak u chorych na DLBCL we wczesnym stadium klinicznego zaawansowania rzadko stwierdza się naciek w BM, jeśli jednocześnie go nie zobrazowano $\mathrm{w}$ badaniu PET-CT. W badaniu przeprowadzonym przez Khan i wsp. [18] zajęcie BM przez DLBCL wykazano u 35 (27\%) spośród 130 chorych, przy czym u $33(94 \%)$ pacjentów w badaniu PET-CT, a tylko u $14(40 \%)$ - w biopsji BM. Wyniki metaanalizy opublikowanej przez Adams i wsp. [19] wskazują również, że zajęcie BM w badaniu PET-CT wystarcza do oceny stopnia zaawansowania DLBCL i dalsze wykonywanie trepanobiopsji BM nie jest rekomendowane. $Z$ kolei negatywny wynik badania PET-CT nie wyklucza całkowicie możliwości nacieczenia BM przez komórki DLBCL i wówczas decyzję o wykonaniu trepanobiopsji należy podjąć na podstawie aktualnej sytuacji klinicznej chorego i wpływu potencjalnego zajęcia BM na decyzje terapeutyczne [19].

\section{Stopień zaawansowania klinicznego}

W klasyfikacji z Lugano z 2014 roku wprowadzono zmiany w ocenie stopnia klinicznego zaawansowania chłoniaków, który do tej pory określano na podstawie skali z Ann Arbor z późniejszą modyfikacją $z$ Cotswolds [1, 2]. W tabeli 2 przedstawiono aktualnie obowiązującą klasyfikację stopnia zaawansowania chłoniaków pierwotnie węzłowych. Stopnie zaawansowania I i II bez zmiany bulky uznaje się za stadium ograniczone choroby, natomiast stopnie III i IV to stadium zaawansowane. Stopień II ze zmianą bulky jest uważany za chorobę ograniczoną lub zaawansowaną zależnie od typu histologicznego chłoniaka i liczby czynników rokowniczych.

Obecność choroby pozawęzłowej określa się jako „E”, przy czym to określenie dotyczy jedynie stopnia I, jeśli stwierdza się tylko pojedynczą zmianę pozawęzłową bez zajęcia węzłów chłonnych (IE) lub stopnia I i II w przypadku zmian węzłowych $z$ ograniczonym umiejscowieniem pozawęzłowym przez ciągłość. Oceny zajęcia pozawęzłowego nie stosuje się wobec stadiów zaawansowania III i IV.

W przypadku chłoniaków o lokalizacji pierwotnie pozawęzłowej, takich jak chłoniak strefy brzeżnej żołądka typu MALT (mucosa-associated lymphoid tissue) czy chłoniaki pierwotnie skórne, przy ocenie stopnia klinicznego zaawansowania należy się posługiwać klasyfikacjami przeznaczonymi dla tych szczególnych postaci NHL [20, 21].

\section{Ocena odpowiedzi na leczenie}

Aktualne rekomendacje dotyczące oceny odpowiedzi na leczenie w przypadku chłoniaków FDG-awidnych ocenianych w PET-CT i chłoniaków FDG-nieawidnych ocenianych za pomocą CT przedstawiono $\mathrm{w}$ tabeli 3. W ocenie odpowiedzi za pomocą PET-CT zaleca się stosowanie 5PS, zarówno do oceny etapowej (IA, interim analysis), określającej wczesną odpowiedź na leczenie, jak i do oceny po zakończeniu leczenia (EOT, end-of-treatment) służącej określeniu jakości uzyskanej odpowiedzi. Jeden punkt (bez wychwytu FDG powyżej tła) i dwa punkty (wychwyt FDG poniżej 
Tabela 2. Klasyfikacja stopnia zaawansowania chłoniaków pierwotnie węzłowych według klasyfikacji z Lugano (źródło [5]) Table 2. Revised staging system for primary nodal lymphomas according to the Lugano classification (source [5])

\begin{tabular}{|c|c|c|}
\hline Stopień & Zmiany węzłowe & Zmiany pozawęzłowe (E) \\
\hline \multicolumn{3}{|l|}{ Ograniczony } \\
\hline I & $\begin{array}{l}\text { Jeden węzeł chłonny lub grupa wę- } \\
\text { złów przyległych }\end{array}$ & $\begin{array}{l}\text { Pojedyncza zmiana pozawęzłowa bez zajęcia węzłów chłon- } \\
\text { nych }\end{array}$ \\
\hline II & $\begin{array}{l}\text { Dwie lub więcej grup węzłowych po } \\
\text { tej samej stronie przepony }\end{array}$ & $\begin{array}{l}\text { Stopień I lub II dla zmian węzłowych z ograniczonym umiej- } \\
\text { scowieniem pozawęzłowym przez ciągłość }\end{array}$ \\
\hline II masywny* & $\begin{array}{l}\text { Stopień II, jak wyżej, ze zmianą ma- } \\
\text { sywną }\end{array}$ & Nie dotyczy \\
\hline \multicolumn{3}{|c|}{ Zaawansowany } \\
\hline III & $\begin{array}{l}\text { Węzły po obu stronach przepony; } \\
\text { węzły powyżej przepony i zajęcie śle- } \\
\text { dziony }\end{array}$ & Nie dotyczy \\
\hline IV & $\begin{array}{l}\text { Dodatkowe zajęcie narządu pozalimfa- } \\
\text { tycznego niesąsiadującego z zajętymi } \\
\text { węzłami chłonnymi }\end{array}$ & Nie dotyczy \\
\hline
\end{tabular}

Uwagi: Zaawansowanie choroby jest oceniane w PET-CT w przypadku chłoniaków awidnych i w CT w przypadku chłoniaków nieawidnych. Migdałki, pierścień Waldeyera i śledzionę uznaje się za tkankę limfatyczną

*Stopień II ze zmianą masywną (bulky) uważa się za chorobę ograniczoną lub zaawansowaną zależnie od typu histologicznego chłoniaka i liczby czynników rokowniczych; PET (positron emission tomography) - pozytonowa tomografia emisyjna; CT (computed tomography) — tomografia komputerowa

lub równy wychwytowi śródpiersia) według 5PS oznacza całkowitą odpowiedź metaboliczną (CMR, complete metabolic response) - zarówno w IA, jak i ocenie EOT. U pacjentów $z$ chłoniakami wrażliwymi na stosowaną chemioterapię obserwuje się zmniejszanie wychwytu FDG w czasie trwania leczenia, dlatego często w IA może być obecna zmiana rezydualna $z$ wychwytem FDG powyżej wychwytu wątroby, a w ocenie EOT chory uzyskuje CMR. Ostatnie badania wskazują również, że chorzy na HL [22], DLBCL [23] i FL [24], którzy uzyskują 3 punkty (wychwyt FDG powyżej wychwytu śródpiersia, ale poniżej lub równy $z$ wychwytem wątroby) według 5PS, mają dobre rokowanie w ocenie EOT w przypadku zastosowania standardowego leczenia. Należy jednak podkreślić, że interpretacja 3 punktów według 5PS zależy od rodzaju chłoniaka, czasu wykonywania oceny (IA czy EOT), sytuacji klinicznej i stosowanego leczenia. W badaniach klinicznych dotyczących zasadności deeskalacji leczenia w zależności od IA, aby uniknąć leczenia o niewystarczającej intensywności, 3 punkty według 5PS uznaje się za nieadekwatną odpowiedź.

W przypadku trudności w ocenie odpowiedzi na leczenie u chorych na HL pomocne może być wykonanie badania CT, w którym stwierdzenie istotnego zmniejszenia masy guza zwykle koreluje $z$ poprawą rokowania $[25,26]$. U chorego, który przy IA uzyskuje 4 punkty (wychwyt FDG umiarkowany, powyżej wychwytu wątroby) lub 5 punktów (wychwyt FDG znacznie wyższy od wychwytu wątroby), według 5PS z wychwytem FDG zmniejszonym w stosunku do badania PET-CT wykonanego przy rozpoznaniu, rozpoznaje się częściową odpowiedź metaboliczną (PMR, partial metabolic response) i wrażliwość chłoniaka na stosowane leczenie. Jeśli natomiast w ocenie EOT u chorego stwierdza się resztkową chorobę $z$ wychwytem FDG o wielkości 4 lub 5 punktów według 5PS, to świadczy to o niepowodzeniu leczenia, nawet jeśli wychwyt FDG jest mniejszy od wyjściowego. U chorego, który uzyskuje 4 lub 5 punktów według 5PS z intensywnością wychwytu FDG, która się nie zmieniła lub zwiększyła w porównaniu $z$ wychwytem wyjściowym i/lub pojawity się nowe ogniska chłoniaka, rozpoznaje się niepowodzenie leczenia — bez względu na to, czy powyższe zmiany obserwuje się w IA czy w ocenie EOT.

W przypadku chłoniaków FDG-nieawidnych oraz w chłoniakach FDG-awidnych przy braku dostępności badania PET-CT odpowiedź na zastosowane leczenia zaleca się oceniać za pomocą badania CT. W tabeli 3 przedstawiono kryteria odpowiedzi u chorych na HL i NHL. Przy ocenie zmian mierzalnych należy obliczyć takie parametry, jak LDi, iloczyn LDi i wymiaru podłużnego zmiany (PPD, cross product of the LDi and perpendicular diameter), SDi oraz sumę iloczynów wymiarów prostopadłych mnogich zmian (SPD, sum of the product of the perpendicular diameters for multiple lessions). Jeśli wyjściowo była obecna mierzalna, zlewająca się masa węzłowa, która po leczeniu rozdzieliła się 
Tabela 3. Kryteria oceny odpowiedzi na leczenie u chorych na chłoniaki według klasyfikacji z Lugano (źródło [5])

Table 3. Revised criteria for response assessment according to the Lugano classification (source [5])

\begin{tabular}{|c|c|c|}
\hline Odpowiedź i umiejscowienie & Odpowiedź na podstawie PET-CT & Odpowiedź na podstawie CT \\
\hline Całkowita & $\begin{array}{l}\text { Całkowita odpowiedź } \\
\text { metaboliczna }\end{array}$ & Całkowita \\
\hline $\begin{array}{l}\text { Węzły chłonne i miejsca } \\
\text { pozalimfatyczne }\end{array}$ & $\begin{array}{l}\text { Punktacja } 1,2 \text { lub } 3^{1} \mathrm{w} 5 \mathrm{PS}^{2^{*}} \\
\mathrm{z} \text { masą resztkową lub bez niej }\end{array}$ & $\begin{array}{l}\text { Wszystkie poniżej: } \\
\text { - zmniejszenie wymiarów wyjściowo ocenianych } \\
\text { i mierzalnych węzłów chłonnych/mas węzłowych } \\
\text { do } \leq 1,5 \mathrm{~cm} \text { w LDi } \\
\text { - brak pozalimfatycznych umiejscowień choroby }\end{array}$ \\
\hline Zmiany niemierzalne & Nie dotyczy & Nieobecne \\
\hline Powiększenie narządów & Nie dotyczy & Zmniejszenie do prawidłowych rozmiarów \\
\hline Nowe zmiany & Brak & Brak \\
\hline Szpik kostny & Brak zmian FDG-awidnych & $\begin{array}{l}\text { Prawidłowy morfologicznie, jeśli morfologicznie } \\
\text { niejednoznaczny, bez cech zajęcia w IHC }\end{array}$ \\
\hline Częściowa & $\begin{array}{l}\text { Częściowa odpowiedź } \\
\text { metaboliczna }\end{array}$ & Częściowa \\
\hline $\begin{array}{l}\text { Węzły chłonne i miejsca } \\
\text { pozalimfatyczne }\end{array}$ & $\begin{array}{l}\text { Punktacja } 4 \text { lub } 5 \text { w 5PS ze zmniej- } \\
\text { szonym wychwytem w porównaniu } \\
\text { z wychwytem wyjściowym } \\
\text { i resztkową masą niezależnie } \\
\text { od jej wymiarów } \\
\text { W ocenie etapowej powyższe } \\
\text { kryterium sugeruje wystąpienie } \\
\text { odpowiedzi na leczenie } \\
\text { W ocenie po zakończeniu leczenia } \\
\text { powyższe kryterium wskazuje na } \\
\text { chorobę resztkową }\end{array}$ & $\begin{array}{l}\text { Wszystkie poniższe: } \\
\text { - zmniejszenie o } \geq 50 \% \text { SPD do } 6 \text { mierzalnych, } \\
\text { ocenianych wyjściowo węzłów chłonnych } \\
\text { lub zmian pozawęzłowych } \\
\text { - jeśli zmiana jest zbyt mała, by zmierzyć ją w CT, } \\
\text { to należy przyjąć jej domyślny wymiar } \\
5 \mathrm{~mm} \times 5 \mathrm{~mm} \\
\text { - jeśli zmiana stała się niewidoczna, } 0 \times 0 \mathrm{~mm} \\
\text { - dla węzłów }>5 \mathrm{~mm} \times 5 \mathrm{~mm} \text {, ale mniejszych } \\
\text { niż prawidłowe, do obliczeń należy używać } \\
\text { ich rzeczywistych wymiarów }\end{array}$ \\
\hline Zmiany niemierzalne & Nie dotyczy & $\begin{array}{l}\text { Nieobecne/prawidłowe, zmniejszone, } \\
\text { ale nie zwiększone }\end{array}$ \\
\hline Powiększenie narządów & Nie dotyczy & $\begin{array}{l}\text { Śledziona musi się zmniejszyć o > 50\% długości } \\
\text { wykraczającej poza prawidłową długość śledziony }\end{array}$ \\
\hline Nowe zmiany & Brak & Brak \\
\hline Szpik kostny & $\begin{array}{l}\text { Resztkowy wychwyt powyżej } \\
\text { wychwytu prawidłowego szpiku, } \\
\text { ale poniżej wychwytu wyjściowego } \\
\text { (dopuszcza się rozlany wychwyt } \\
\text { odpowiadający odnowie } \\
\text { po chemioterapii). Jeśli występują } \\
\text { przetrwałe zmiany ogniskowe } \\
\text { w szpiku przy jednoczesnej odpowie- } \\
\text { dzi węzłowej, to należy rozważyć } \\
\text { dalszą ocenę za pomocą NMR, } \\
\text { biopsji szpiku lub kontrolnego } \\
\text { PET-CT po pewnym czasie }\end{array}$ & Nie dotyczy \\
\hline
\end{tabular}

\begin{tabular}{lll}
\hline $\begin{array}{l}\text { Brak odpowiedzi lub choroba } \\
\text { stabilna }\end{array}$ & Brak odpowiedzi metabolicznej & Choroba stabilna \\
\hline $\begin{array}{l}\text { Oceniane, mierzalne węzły } \\
\text { chłonne/masy węzłowe, } \\
\text { zmiany pozawęzłowe }\end{array}$ & $\begin{array}{l}\text { Punktacja 4 lub 5 w 5PS w ocenie } \\
\text { etapowej lub po zakończeniu lecze- } \\
\text { nia, bez istotnych różnic wychwytu } \\
\text { FDG w porównaniu z wyjściowym }\end{array}$ & $\begin{array}{l}\text { Zmniejszenie o < 50\% SPD do 6 dominujących, } \\
\text { pozawerzych węzłów chłonnych lub zmian } \\
\text { choroby progresywnej }\end{array}$ \\
Zmiany niemierzalne & Nie dotyczy & $\begin{array}{l}\text { Bez zwiększenia odpowiadającego chorobie } \\
\text { progresywnej } \\
\text { Powiększenie narządów }\end{array}$ \\
Nowe zmiany & Nie dotyczy & $\begin{array}{l}\text { Bez zwiększenia odpowiadającego chorobie } \\
\text { progresywnej }\end{array}$ \\
Szpik kostny & Brak & Brak \\
& Bez różnicy w porównaniu z oceną \\
wyjściową & Nie dotyczy \\
\hline
\end{tabular}


Tabela 3 (cd.). Kryteria oceny odpowiedzi na leczenie u chorych na chłoniaki według klasyfikacji z Lugano (źródło [5])

Table 3 cont. Revised criteria for response assessment according to the Lugano classification (source [5])

\begin{tabular}{|c|c|c|}
\hline Choroba progresywna & $\begin{array}{l}\text { Progresywna choroba metabo- } \\
\text { liczna }\end{array}$ & Choroba progresywna \\
\hline $\begin{array}{l}\text { Jeden oceniany, mierzalny węzeł } \\
\text { chłonny/masy węzłowe } \\
\text { Zmiany pozawęzłowe }\end{array}$ & $\begin{array}{l}\text { Punktacja } 4 \text { lub } 5 \text { w } 5 \text { PS ze zwięk- } \\
\text { szoną intensywnością wychwytu } \\
\text { FDG w porównaniu z wyjściowym } \\
\text { i/lub nowe, odpowiadające chłonia- } \\
\text { kowym, zmiany FDG-awidne stwier- } \\
\text { dzane podczas oceny etapowej lub } \\
\text { po zakończeniu leczenia }\end{array}$ & $\begin{array}{l}\text { Konieczne } \geq 1 \text { kryterium PPD z poniższych: } \\
\text { - pojedynczy węzet/zmiana muszą być nieprawid- } \\
\text { łowe w zakresie: LDi }>1,5 \mathrm{~cm} \text { i zwiększył się } \\
\text { o } \geq 50 \% \text { od nadiru PPD i zwiększenie od nadiru } \\
\text { LDi lub SDi o } 0,5 \mathrm{~cm} \text { dla zmian } \leq 2 \mathrm{~cm} \text {, } \\
\text { lub o } 1 \mathrm{~cm} \text { dla zmian }>2 \mathrm{~cm} \\
\text { - jeśli wyjściowo występowała splenomegalia, } \\
\text { to zwiększenie o }>50 \% \text { długości w porównaniu } \\
\text { z wyjściową liczoną od wartości wykraczającej } \\
\text { poza prawidłową długość śledziony } \\
\text { - jeśli wyjściowo nie występowała splenomegalia, } \\
\text { to zwiększenie jej długości o } \geq 2 \mathrm{~cm} \\
\text { w porównaniu z wyjściową } \\
\text { - nowa lub pojawiająca się ponownie } \\
\text { splenomegalia }\end{array}$ \\
\hline
\end{tabular}

Zmiany niemierzalne Brak

Nowe zmiany

Szpik kostny
Nowe zmiany FDG-awidne, bardziej odpowiadające zmianom chłoniakowym niż o innej etiologii (infekcja, zapalenie). Jeśli etiologia nowych zmian jest niepewna, to wskazana jest biopsja zmiany lub kontrolne badanie PET-CT po pewnym czasie
Nowe zmiany lub ewidentna progresja zmian niemierzalnych wcześniej obserwowanych

Ponowne pojawienie się zmian, które wcześniej uległy regresji

Nowy węzeł $>1,5 \mathrm{~cm}$ w dowolnej osi

Nowa zmiana pozawęzłowa $>1 \mathrm{~cm}$ w dowolnej osi; jeśli zmiana jest $<1 \mathrm{~cm}$ w każdej osi, to musi być niewątpliwa i odpowiadać zmianie chłoniakowej

Możliwa do oceny zmiana niezależnie od wymiarów jednoznacznie odpowiadająca zmianie chłoniakowej

Nowe lub ponowne zajęcie szpiku

1Dominujące mierzalne zmiany: $\leq 6$ największych dominujących węzłów chłonnych, mas węzłowych i zmian pozawęzłowych dających się łatwo zmierzyć w dwóch wymiarach. Zaleca się, aby wybrane węzły były zlokalizowane w różnych regionach ciała i, jeśli ma to zastosowanie, powinny obejmować śródpiersie i okolicę pozaotrzewnową. Zmiany pozawęzłowe obejmują narządy miąższowe (np. wątrobę, śledzionę, nerki, płuca), przewód pokarmowy, zmiany skórne lub wyczuwalne przy badaniu palpacyjnym. Zmiany niemierzalne: każda zmiana niezakwalifikowana jako mierzalna; może dotyczyć węzłów chłonnych, mas węzłowych lub zmian pozawęzłowych, których nie uznano za dominujące lub mierzalne albo zmian, których nie można zmierzyć w dwóch wymiarach lub monitorować ilościowo, w tym płyn w jamie opłucnej, wodobrzusze, zmiany w kościach, zmiany w oponach mózgowo-rdzeniowych, masy w jamie brzusznej i inne zmiany, które nie mogą być potwierdzone i monitorowane za pomoca badań obrazowych. W obrebie pierścienia Waldeyera lub w lokalizacjach pozawezłowych (np. w przewodzie pokarmowym, wątrobie, szpiku kostnym) wychwyt FDG może być większy niż w śródpier z pełną odpowiedzią metaboliczna, ale nie powinien być większy niż otaczający wychwyt fizjologiczny (np. W szpiku wych kostnym wynikający z chemioterapii lub krwiotwórczych czynników wzrostu); 2PET 5PS: 1) bez wychwytu powyżej tła; 2) wychwyt $\leq$ śródpiersia; 3) wychwyt > śródpie sia, ale $\leq$ od wątroby; 4) wychwyt umiarkowanie > od wątroby; 5) wychwyt znacznie wyższy od wątroby i/lub nowe zmiany; X) nowe obszary wychwytu niewskazujące na chłoniaka; * przyjmuje się, że wychwyt w pierścieniu Waldeyera lub lokalizacjach pozawęzłowych z wysokim fizjologicznym wychwytem FDG lub wychwytem w śledzionie lub szpiku (np. po chemioterapii lub czynnikach wzrostu) może przekraczać prawidłowy wychwyt śródpiersia i/lub wątroby. W takich przypadkach odpowiedź metaboliczną można uznać za całkowitą, jeśli wychwyt w wyjściowo zajętych obszarach nie jest większy niż w otaczających prawidłowych tkankach, nawet jeśli tkanka ma wysoki wychwyt fizjologiczny; PET (positron emission tomography) - pozytonowa tomografia emisyjna; CT (computed tomography) - tomografia komputerowa; 5PS (5-point scale) - skala 5-punktowa; LDi (longest transverse diameter of a lesion) - najdłuższy poprzeczny wymiar zmiany; FDG (fluorodeoxyglucose) - fluorodeoksyglukoza; IHC (immunohistochemistry) - immunohistochemia; SPD (sum of the product of the perpendicular diameters for multiple lessions) - suma iloczynów wymiarów prostopadłych mnogich zmian; NMR (nuclear magnetic resonance) - jądrowy rezonans magnetyczny; PPD (cross product of the LDi and perpendicular diameter) - iloczyn LDi i wymiaru podłużnego zmiany; SDi (shortest axis perpendicular to the LDi) - najkrótszy wymiar podłużny prostopadły do LDi

na kilka odrębnych węzłów chłonnych, to przy ocenie odpowiedzi należy zsumować PPD pozostałej masy z PPD oddzielnych węzłów chłonnych. Jeśli obserwuje się zwiększenie wymiarów jakiegokolwiek węzła chłonnego lub wszystkich węzłów, to ewentualną progresję choroby (PD, progression disease) należy oceniać, licząc od nadiru każdego węzła chłonnego, jeśli poszczególne węzły zakwalifikowano jako zmiany oceniane wyjściowo (target nodes). Jeśli mierzalne, wyjściowo oceniane węzły połączyły się po leczeniu w jedną masę węzłową, to przy ocenie odpowiedzi należy porównać PPD aktualnej masy węzłowej z sumą PPD wyjściowych węzłów - jeśli aktualne PPD jest większe o 50\%, to wtedy można rozpoznać PD. Ocena LDi i SDi nie jest wówczas konieczna. Należy podkreślić, że przy ocenie za pomocą badania CT obecność przetrwałej zmiany o wymiarach mniejszych od wyjściowych uznaje się za odpowiedź częściową (PR, partial response), jeśli jednocześnie nie wykonuje się biopsji zmiany mogącej potwierdzić brak nacieku chłoniaka, gdyż w obecnej klasyfikacji termin CRu 
nie ma już zastosowania [5]. Stosując nowoczesne leki wywołujące reakcję typuflare, należy zachować ostrożność, aby początkowego zwiększenia masy guza wywołanego reakcją flare nie pomylić z PD chłoniaka. Zaleca się wykonanie albo biopsji zmiany, albo ponownej oceny po przynajmniej 2 tygodniach — jeśli zmiana nadal będzie się powiększała, to można rozpoznać $\mathrm{PD} z$ datą poprzedniej oceny.

\section{Obserwacja po leczeniu}

Według rekomendacji European Society for Medical Oncology (ESMO) i NCCN częstość wizyt kontrolnych po zakończeniu leczenia zależy od tego, czy chłoniak jest potencjalnie uleczalny czy nieuleczalny, czy chory jest leczony w ramach badania klinicznego czy codziennej praktyki klinicznej oraz od sytuacji klinicznej (leczenie indukujące $v$. nawrót/progresja, całkowita odpowiedź [CR, complete response $] v$. PR) $[4,11,27]$.

W przypadku chłoniaków potencjalnie uleczalnych, takich jak na przykład HL i DLBCL, prawdopodobieństwo nawrotu zmniejsza się w czasie. Dlatego przez pierwsze 2 lata wizyty powinny się odbywać co 3 miesiące, następnie co 6 miesięcy przez kolejne 3 lata, a później raz na rok w celu monitorowania ewentualnego późnego nawrotu i późnej toksyczności leczenia. W przypadku chłoniaków nieuleczalnych, takich jak na przykład FL czy MCL, prawdopodobieństwo nawrotu/progresji jest stałe lub nawet wzrasta $z$ czasem, dlatego chorego powinno się obserwować co 3-6 miesięcy w zależności od wyjściowych czynników ryzyka i osiągniętej odpowiedzi (CR czy brak CR). Dodatkowo zaleca się wykonywanie morfologii krwi obwodowej, badań biochemicznych i pomiaru aktywności LDH.

Nie zaleca się wykonywania badań obrazowych rutynowo, a jedynie $\mathrm{w}$ sytuacjach klinicznie uzasadnionych. Częstość fałszywie dodatnich wyników badań PET sięga $20 \%$ i naraża chorego na niepotrzebne napromienianie, biopsje i niepokój. Należy jednak podkreślić, że w przypadku chłoniaków indolentnych $z$ resztkowymi węzłami chłonnymi po leczeniu, które są zlokalizowane w obrębie jamy brzusznej lub zewnątrzotrzewnowo, zaleca się wykonywanie badań obrazowych, ale rozważne [5].

\section{Podsumowanie}

Według obecnie obowiązujących rekomendacji $z$ Lugano badanie PET-CT $z$ oceną według 5PS powinno być standardem przy rozpoznaniu, a następnie przy ocenie odpowiedzi na leczenie w przypadku chorego na chłoniaka FDG-awidnego. W przypadku chorych na chłoniaki FDG-nieawidne przy rozpoznaniu i ocenie odpowiedzi należy wykonywać badanie CT. Progresję choroby na podstawie badania CT można rozpoznać w przypadku odpowiedniego zwiększenia wymiarów już pojedynczego węzła chłonnego. Podstawą w wyborze leczenia powinna być obecność lub brak czynników ryzyka, przy czym objawy ogólne wydają się mieć znaczenie prognostyczne jedynie w przypadku HL. Przy rozpoznaniu chłoniaka badanie trepanobiopsyjne BM może nie być konieczne, szczególnie w HL i większości przypadków DLBCL. Zmiana bulky jest dobrze zdefiniowana dla HL; w odniesieniu do pozostałych podtypów NHL konieczne są dalsze badania, które wskażą, jaki wymiar zmiany bulky koreluje $z$ niekorzystnymi wynikami leczenia.

\section{Piśmiennictwo}

1. Rosenberg S.A. Validity of the Ann Arbor staging classification for the non-Hodgkin's lymphomas. Cancer Treat. Rep. 1977; 61: 1023-7102.

2. Lister T.A., Crowther D., Sutcliffe S.B. i wsp. Report of a committee convened to discuss the evaluation and staging of patients with Hodgkin's disease: Cotswolds meeting. J. Clin. Oncol. 1989; 7: 1630-1636.

3. Cheson B.D., Horning S.J., Coiffier B. i wsp. Report of an international workshop to standardize response criteria for non-Hodgkin's lymphomas. NCI Sponsored International Working Group. J. Clin. Oncol. 1999; 17: 1244. Erratum in: J. Clin. Oncol. 2000; 18: 2351.

4. Cheson B.D., Pfistner B., Juweid M.E. i wsp.; International Harmonization Project on Lymphoma. Revised response criteria for malignant lymphoma. J. Clin. Oncol. 2007; 25: 579-586.

5. Cheson B.D., Fisher R.I., Barrington S.F. i wsp.; Alliance, Australasian Leukaemia and Lymphoma Group; Eastern Cooperative Oncology Group; European Mantle Cell Lymphoma Consortium; Italian Lymphoma Foundation; European Organisation for Research; Treatment of Cancer/Dutch Hemato-Oncology Group; Grupo Español de Médula Ósea; German High-Grade Lymphoma Study Group; German Hodgkin's Study Group; Japanese Lymphorra Study Group; Lymphoma Study Association; NCIC Clinical Trials Group; Nordic Lymphoma Study Group; Southwest Oncology Group; United Kingdom National Cancer Research Institute. Recommendations for initial evaluation, staging, and response assessment of Hodgkin and non-Hodgkin lymphoma: the Lugano classification. J. Clin. Oncol. 2014; 32: 3059-3068.

6. Czyż A. Postępy w leczeniu wspomagającym u chorych na nowotwory układów chłonnego i krwiotwórczego. Hematologia 2015; 6: 77-84.

7. The International Non-Hodgkin's Lymphoma Prognostic Factors Project. A predictive model for aggressive non-Hodgkin's lymphoma. N. Engl. J. Med. 1993; 329: 987-994.

8. Solal-Céligny P., Roy P., Colombat P. i wsp. Follicular lymphoma international prognostic index. Blood 2004; 104: 1258-1265.

9. Hoster E., Dreyling M., Klapper W. i wsp.; German Low Grade Lymphoma Study Group (GLSG); European Mantle Cell Lymphoma Network. A new prognostic index (MIPI) for patients 
with advanced-stage mantle cell lymphoma. Blood 2008; 111: 558-565.

10. Federico M., Bellei M., Marcheselli L. i wsp. Follicular lymphoma international prognostic index 2: a new prognostic index for follicular lymphoma developed by the international follicular lymphoma prognostic factor project. J. Clin. Oncol. 2009; 27: 4555-4562.

11. Pfreundschuh M., Ho A.D., Cavallin-Stahl E. i wsp.; MabThera International Trial (MInT) Group. Prognostic significance of maximum tumour (bulk) diameter in young patients with good-prognosis diffuse large B-cell lymphoma treated with CHOP-like chemotherapy with or without rituximab: an exploratory analysis of the MabThera International Trial Group (MInT) study. Lancet Oncol. 2008; 9: 435-444.

12. Zelenetz A.D., Gordon L.I., Wierda W.G. i wsp.; National Comprehensive Cancer Network. Non-Hodgkin's lymphomas, version 4.2014. J. Natl. Compr. Canc. Netw. 2014; 12: 1282-1303.

13. NCCN Clinical Practice Guidelines in Oncology version 2.2015. Dostępne na: www.nccn.org.

14. El-Galaly T.C., d'Amore F., Mylam K.J. i wsp. Routine bone marrow biopsy has little or no therapeutic consequence for positron emission tomography/computed tomography-staged treatment-naïve patients with Hodgkin lymphoma. J. Clin. Oncol. 2012; 30: 4508-1454.

15. Carr R., Barrington S.F., Madan B. i wsp. Detection of lymphoma in bone marrow by whole-body positron emission tomography. Blood 1998; 91: 3340-3346.

16. Pelosi E., Penna D., Douroukas A. i wsp. Bone marrow disease detection with FDG-PET/CT and bone marrow biopsy during the staging of malignant lymphoma: results from a large multicentre study. QJ Nucl. Med. Mol. Imaging 2011; 55: 469-475.

17. Berthet L., Cochet A., Kanoun S. i wsp. In newly diagnosed diffuse large B-cell lymphoma, determination of bone marrow involvement with 18F-FDG PET/CT provides better diagnostic performance and prognostic stratification than does biopsy. J. Nucl. Med. 2013; 54: 1244-1250.

18. Khan A.B., Barrington S.F., Mikhaeel N.G. i wsp. PET-CT staging of DLBCL accurately identifies and provides new insight into the clinical significance of bone marrow involvement. Blood 2013; 122: 61-67.

19. Adams H.J., Kwee T.C., de Keizer B. i wsp. FDG PET/CT for the detection of bone marrow involvement in diffuse large B-cell lymphoma: systematic review and meta-analysis. Eur. J. Nucl. Med. Mol. Imaging 2014; 41: 565-574.
20. Zucca E., Copie-Bergman C., Ricardi U. i wsp.; ESMO Guidelines Working Group. Gastric marginal zone lymphoma of MALT type: ESMO Clinical Practice Guidelines for diagnosis, treatment and follow-up. Ann. Oncol. 2013; 24 (supl. 6): 144-148.

21. Olsen E.A., Whittaker S., Kim Y.H. i wsp.; International Society for Cutaneous Lymphomas; United States Cutaneous Lymphoma Consortium; Cutaneous Lymphoma Task Force of the European Organisation for Research and Treatment of Cancer. Clinical end points and response criteria in mycosis fungoides and Sézary syndrome: a consensus statement of the International Society for Cutaneous Lymphomas, the United States Cutaneous Lymphoma Consortium, and the Cutaneous Lymphoma Task Force of the European Organisation for Research and Treatment of Cancer. J. Clin. Oncol. 2011; 29: 2598-2607.

22. Biggi A., Gallamini A., Chauvie S. i wsp. International validation study for interim PET in ABVD-treated, advanced-stage Hodgkin lymphoma: interpretation criteria and concordance rate among reviewers. J. Nucl. Med. 2013; 54: 683-690.

23. Pregno P., Chiappella A., Bellò M. i wsp. Interim 18-FDG-PET/ /CT failed to predict the outcome in diffuse large B-cell lymphoma patients treated at the diagnosis with rituximab-CHOP. Blood 2012; 119: 2066-7203.

24. Dupuis J., Berriolo-Riedinger A., Julian A. i wsp. Impact of [(18)F] fluorodeoxyglucose positron emission tomography response evaluation in patients with high-tumor burden follicular lymphoma treated with immunochemotherapy: a prospective study from the Groupe d'Etudes des Lymphomes de l'Adulte and GOELAMS. J. Clin. Oncol. 2012; 30: 4317-4322.

25. Kostakoglu L., Schöder H., Johnson J.L. i wsp.; Cancer Leukemia Group B. Interim [(18)F]fluorodeoxyglucose positron emission tomography imaging in stage I-II non-bulky Hodgkin lymphoma: would using combined positron emission tomography and computed tomography criteria better predict response than each test alone? Leuk. Lymphoma 2012; 53: 2143-2150.

26. Kobe C., Kuhnert G., Kahraman D. i wsp. Assessment of tumor size reduction improves outcome prediction of positron emission tomography/computed tomography after chemotherapy in advanced-stage Hodgkin lymphoma. J. Clin. Oncol. 2014; 32: 1776-1781.

27. Ghielmini M., Vitolo U., Kimby E. i wsp.; Panel Members of the 1st ESMO Consensus Conference on Malignant Lymphoma. ESMO Guidelines consensus conference on malignant lymphoma 2011 part 1: diffuse large B-cell lymphoma (DLBCL), follicular lymphoma (FL) and chronic lymphocytic leukemia (CLL). Ann. Oncol. 2013; 24: 561-576. 